\title{
Título da página eletrónica: LabforCulture.org
}

URL: http://www.labforculture.org/

\section{Pedro Quintela}

\section{OpenEdition}

\section{Journals}

Edição electrónica

URL: http://journals.openedition.org/rccs/5079

DOI: $10.4000 /$ rccs.5079

ISSN: 2182-7435

\section{Editora}

Centro de Estudos Sociais da Universidade de Coimbra

Edição impressa

Data de publição: 1 setembro 2012

Paginação: 125-126

ISSN: 0254-1106

Refêrencia eletrónica

Pedro Quintela, «Título da página eletrónica: LabforCulture.org », Revista Crítica de Ciências Sociais [Online], 98 | 2012, posto online no dia 06 junho 2013, consultado o 22 setembro 2020. URL : http:// journals.openedition.org/rccs/5079; DOI : https://doi.org/10.4000/rccs.5079 


\section{Espaço Virtual}

\section{Título da página eletrónica: Musing on Culture URL: http://musingonculture-pt.blogspot.pt/}

Os blogues pessoais utilizados enquanto espaços de reflexão e partilha de informação são hoje um fenómeno de comunicação que interessa seguir, pois muitas vezes antecipam tendências e/ou amplificam discussões em torno de temas relevantes para determinados setores. O Musing on Culture é um projeto de Maria Vlachou que pretende contribuir para a consolidação de um pensamento crítico e plural no seio do setor cultural. Os assuntos e as temáticas abordados são variados, embora seja possível identificar alguns aspetos focados recorrentemente no Musing on Culture, tais como a acessibilidade a estruturas culturais; políticas culturais, financiamento e apoio às artes; accountability na gestão de projetos e estruturas culturais e artísticas; os equipamentos culturais (em particular, os museus) como espaços de participação e envolvimento cívico e comunitário; aspetos relacionados com a organização e gestão de instituições culturais (tais como a liderança, a comunicação e marketing, a política de preços e de fidelização de públicos, entre outros). Disponível em português e inglês, encontramos neste blogue não só artigos de opinião de Maria Vlachou, como também posts de bloggers convidados que partilham reflexões sobre temáticas de algum modo transversais ao setor, mas também apresentam e analisam estudos de casos sobre projetos e instituições artísticas e culturais de referência. Para além de ser possível consultar Musing on Culture de forma sequencial e cronológica, o blogue permite ainda o acesso aos textos por temas e palavras-chave. Outro aspeto interessante e útil para quem pretenda aprofundar algumas das temáticas abordadas no Musing on Culture, prende-se com o facto de, em geral, os posts disponibilizarem não só informação atualizada sobre diversos projetos e instituições, mas também referências bibliográficas, vídeos e outros documentos disponíveis na Web. Foi recentemente publicado (Bypass Editions, 2013) o livro Musing on Culture, que reúne uma seleção de alguns dos textos publicados por Maria Vlachou no blogue.

\section{Título da página eletrónica: LabforCulture.org URL: http://www.labforculture.org/}

A circulação e partilha de informações, os métodos de trabalho colaborativos e em rede são hoje verdadeiros paradigmas no modo de organização de diversos tipos de instituições, constituindo a Internet uma poderosa ferramenta para potenciar estes processos. O LabforCulture é uma iniciativa do European Cultural Foundation (Amesterdão), iniciado em 2004, que visa fomentar o networking entre agentes culturais e artísticos europeus, facilitando a colaboração e partilha de dados. O website disponibiliza informação em cinco idiomas (alemão, francês, inglês, italiano e polaco) e está estruturado, de forma bastante intuitiva, em diversas secções. Inclui, assim, uma secção de notícias relacionadas com o setor cultural e criativo (seleção de 
notícias online, newletters, fóruns e mailing lists, calendário de eventos); um diretório de agentes e instituições culturais (redes, organizações, associações, públicas e privadas, "oficiais" e "independentes"); uma secção dedicada ao financiamento (de projetos, iniciativas e organizações, contemplando ainda informação sobre esquemas de mobilidade, apoios de fundações e outros organismos, ferramentas para angariação de patrocínios, apoios mecenáticos e outras formas de financiamento, como o crowdfunding, por exemplo); vários estudos de casos e uma base de dados de projetos transfronteiriços de cooperação no espaço Europeu; uma secção intitulada "recursos para pesquisa", com uma seleção de publicações, artigos e dossiers temáticos (alguns deles da responsabilidade da equipa do LabforCulture), guias metodológicos e instrumentos de recolha de informação e pesquisa, e também o acesso a uma extensa base de dados de artistas, curadores, instituições culturais e investigadores e centros de investigação e formação; finalmente, a secção "comunidade" disponibiliza informação sobre eventos, blogues, fóruns, etc. Para além da grande amplitude de dados reunidos e disponibilizados gratuitamente, um dos aspetos mais interessantes reside na forma apurada como são trabalhados os "filtros" de pesquisa, facilitando a busca de informação, e tornando o LabforCulture uma ferramenta de trabalho bastante útil tanto para fins académicos, como profissionais.

Pedro Quintela

\section{Título da página eletrónica: Observatório Internacional de Democracia Participativa URL: http://www.oidp.net/}

O Observatório Internacional de Democracia Participativa é uma rede de entidades, organizações e centros de investigação de mais de 500 cidades de todo o mundo. Nasceu em 2001 no âmbito dos Projetos de Cooperação Descentralizada do Programa URB-AL da Comissão Europeia, coordenado pela cidade de Barcelona. Dedica-se a conhecer, trocar e aplicar experiências sobre democracia participativa ao nível local.

O sítio eletrónico apresenta informação útil para áreas de investigação relacionadas com governação local e práticas de democracia participativa, sendo possível identificar experiências em todo o mundo. Apesar de não conter informação sobre os projetos de todos os membros da rede, pode ser muito útil na identificação de casos de estudo e no apoio à revisão de estados da arte naquelas temáticas.
A Secretaria Técnica do OIDP tem sede na Câmara Municipal de Barcelona, contando ainda com escritórios regionais na América Latina e em África. A Presidência é exercida por uma cidade pertencente a um continente diferente em cada ano, sendo escolhida por consenso na conferência anual do OIDP. Este ano a Presidência cabe à Câmara Municipal de Cascais e a conferência anual terá lugar em Cascais, de 2 a 5 de julho.

A rede está aberta a membros sócios por parte de municípios e administrações locais e a membros colaboradores por parte de entidades, associações, fundações e organizações ligadas aos governos locais e centros de estudos, investigação e universidades, podendo os primeiros candidatar-se à Distinção de Boas Práticas em Participação Cidadã e os segundos participar como júri. Atualmente a composição é de 310 sócios 
e 237 colaboradores. Portugal integra 16 membros. Embora seja possível procurar membros através de um motor de busca, não é apresentada informação sobre os projetos de cada membro, sendo apenas disponibilizada a hiperligação para o sítio eletrónico de cada um. É possível, no entanto, encontrar informação mais detalhada dos projetos dos membros que se candidataram à Distinção OIDP e informação bastante estruturada dos projetos dos membros vencedores da referida Distinção.

Entre os projetos do OIDP, destacam-se os Observatórios Locais de Democracia Participativa, uma rede que tem como objetivo desenvolver metodologias de avaliação da participação a partir de contextos políticos, sociais, económicos e territoriais diferentes. No entanto, não está disponível mais informação sobre estes Observatórios, nomeadamente sobre a sua atividade ou localização.

O sítio eletrónico está disponível em português, inglês, francês, espanhol e catalão e oferece ao visitante um Centro de Recursos onde é possível encontrar informação sobre projetos nacionais e internacionais na área da democracia participativa, destacando-se:

- A biblioteca, na qual se pode consultar uma descrição dos projetos vencedores e dos projetos candidatos por ano da Distinção OIDP Boas Práticas em Participação Cidadã e onde se encontram hiperligações para os sites das conferências internacionais OIDP de 2006 a 2009 e de 2012.

- A mediateca com documentários de curta duração sobre casos de cidades que conduzem experiências e processos de democracia participativa.

- O motor de busca para casos de estudo com possibilidades de pesquisa através de país, tipo de experiência e âmbito populacional.

- Os regulamentos de participação cidadã e direito (de momento dois, um da República Dominicana, outro de Itália).

- Os guias metodológicos, entre os quais se destacam o Guia de avaliação de processos participativos e o Guia de deteção de boas práticas em processos participativos.

\section{Título da página eletrónica: City for All Women Initiative/Initiative: une ville pour toutes les femmes URL: http://www.cawi-ivtf.org/}

City For All Women Initiative (CAWI) é uma organização colaborativa de mulheres de diversas comunidades, organizações e centros de investigação da cidade de Otava, no Canadá. Tem como objetivos fundamentais capacitar as mulheres para participarem na governação local e nos processos de tomada de decisão municipais e criar uma cidade mais inclusiva e promotora da igualdade de género. Promove o desenvolvimento de conhecimento sobre o modo de governação da cidade junto dos seus membros, incluindo mulheres
Aborígenes, com necessidades especiais, com baixos rendimentos, francófonas ou imigrantes. Através do desenvolvimento de competências de facilitação e comunicação, a CAWI pretende que os seus membros desenvolvam competências de engajamento das suas comunidades.

A organização nasceu em 2004, tendo na sua origem dois projetos de investigação que integraram mulheres de diversas comunidades e organizações da cidade: "O acesso das mulheres aos serviços municipais", em 2002 e "O acesso das mulheres 
à tomada de decisão municipal”, em 2005. Nestes estudos revelou-se a necessidade de incluir as questões de género e diversidade, de uma forma sistemática, nos processos de tomada de decisão do Município. O Município reconheceu, em 2004, a CAWI como parceira comunitária e aprovou a colaboração do Departamento de Serviços Comunitários e de Proteção com a organização.

O sítio eletrónico contém informação relevante para áreas de investigação relacionadas com a participação de mulheres na governação local, podendo apoiar, de um modo global, estados da arte sobre práticas de governação local, democracia participativa e estudos de género, mas também uma pesquisa mais detalhada de uma experiência participativa feminina no Canadá.

Sendo Otava uma cidade bilingue, o sítio apresenta toda a informação em inglês e francês. Contém um manancial de recursos interessante, nomeadamente guias práticos resultantes da experiência dos membros da organização em liderar iniciativas comunitárias e envolver os cidadãos da sua comunidade. As ilustrações e imagens revelam e celebram a diversidade dos membros da organização e das cidadãs de Otava.

Estão também disponíveis relatórios resultantes de projetos conduzidos pela organização em parceria com outras entidades. Entre estes destacam-se os relatórios do projeto Lentes de Equidade e Inclusão, realizado em parceria com o Município com o objetivo de investigar necessidades específicas de inclusão, onde se explora a diversidade social das comunidades urbanas de Otava, resultando em relatórios muito detalhados sobre 11 comunidades: Aborígenes, francófonos, GLBT (gays, lésbicas, bissexuais e transexuais), pessoas a viver na pobreza, pessoas com necessidades especiais, comunidades rurais, seniores, minorias visíveis, mulheres e jovens.

O sítio eletrónico oferece ainda pequenos vídeos sobre ações da organização, informação sobre outras organizações de mulheres em Otava e ainda várias hiperligações interessantes, particularmente sobre outras experiências de integração de mulheres na governação urbana e sítios onde se podem encontrar ferramentas úteis para a participação na governação.

O modelo de governação da CAWI está disponível no sítio eletrónico, de uma forma bastante detalhada, permitindo ao visitante obter uma perceção bastante aproximada ao modo de funcionamento da organização e ao modelo de tomada de decisão. É mais difícil encontrar informação sobre os efeitos e resultados das suas ações, apesar de serem disponibilizados alguns números relativamente ao número de mulheres participantes nas ações de formação. 